\title{
Environmentally related impacts on financial reporting: the case of pollution permits in Czech legislative conditions
}

\author{
J. Horák \& O. Malíková \\ Faculty of Economics, Technical University of Liberec, Czech Republic
}

\begin{abstract}
The Czech Republic was one of the biggest air polluters in Europe before the year 1989. Czech industry was restructured from heavy to light industry as a consequence of the transition from a centrally planned economy to a market economy after the political, social, economic and other changes that took place that year. The Czech Republic became a member of the European Union in 2004. Due to the membership it was crucial to implement environmental legislation that ensures the reduction of greenhouse gas emissions. The submitted paper deals with problems of pollution permits from the view of Czech accounting legislation. The purpose of financial accounting is to generate financial information about a company in order to provide a basis for transparency and accountability relationships with stakeholders. Financial reporting is used by managers to communicate the dated financial information to external parties. The main environmental topics in a company's financial accounting are the recognition, measurement and disclosure of environmentally related economic impacts on business and a company value. Local financial accounting standards differ between jurisdictions and can substantially influence the economic results of a company. When examining sustainable development and accountability it is crucial to investigate how environmental issues are dealt with by financial reporting rules, whether and when environmentally induced financial outlays should be classified as assets or as expenses. The aim of this paper is to discuss the influence of pollution permits on Czech financial reporting with the view of accounting entity that pollutes air by greenhouse gases. The paper describes problems of a present situation of recording accounting transactions connected with pollution permits such as a purchase or donation of permits, their evidence in Czech financial accounting. The paper analyzes implementation of the EU
\end{abstract}


environmental legislation into Czech national law and it is focused on Czech companies that have an obligation to obtain pollution permits. This situation influences financial accounting and reporting of financial statements.

Keywords: air pollution, pollution permits, emission allowances, environmental accounting, financial reporting, intangible fixed assets, expenses, emissions trading, balance sheet, greenhouse gases, environmental legislation.

\section{Introduction}

The submitted paper deals with problems of air pollution by greenhouse gases and the tools that should decrease their amount in the atmosphere. The first part of the paper is focused on emissions of $\mathrm{CO}_{2}$ in the Czech Republic, the second section discusses auctioning of pollution permits (allowances) in the European Union and the third part analyses described problems in Czech conditions with a focus on financial reporting.

The Kyoto Protocol is an international environmental treaty that concentrates on the decreasing of greenhouse gases such as carbon dioxide $\left(\mathrm{CO}_{2}\right)$, nitrous oxide $\left(\mathrm{N}_{2} \mathrm{O}\right)$, methane $\left(\mathrm{CH}_{4}\right)$, perfluorocarbons (PFCs), hydroflourocarbons (HFCs) and sulphur hexafluoride $\left(\mathrm{SF}_{6}\right)$ in the atmosphere [1].

Since the European Union joined the Kyoto Protocol, it was important to create a specific tool (the Emissions Trading Scheme) that could ensure reduction of greenhouse gases produced by companies situated in the European Union. The system focuses on companies with installations with a net heat supply more than 20MW (e.g. power plants), steel production (capacity exceeds 2.5 tons per hour), cement production (capacity exceeds 50 tons per day), glass production (capacity exceeds 20 tons per day), production of ceramic products (capacity exceeds 75 tons per day) and production of paper if capacity exceeds 20 tons per day [2]. Airlines flying to or from Europe will join the Emissions Trading Scheme in 2012. With ratification of the 2002 Kyoto Protocol all European member states have to reduce their emissions of $\mathrm{CO}_{2}$ to $8 \%$ below the emissions level reached in 1990 by 2012 [3].

Due to meeting of criteria of the Kyoto Protocol by joined countries there are other systems that should ensure reduction of emission of greenhouse gases all over the world such as systems valid in the USA, Australia, Japan, New Zealand etc. The submitted paper focuses on the European Union especially on the Czech Republic and analyses the impact of emission allowances on financial reporting.

\section{Emissions of $\mathrm{CO}_{2}$ in the Czech Republic}

The Czech Republic was one of the largest polluters in Europe before 1990. This situation was caused by the structure of economy that was primarily focused on a heavy industry. After the political changes in 1989 there came changes in the structure of economy with specialization in light industry and services.

Figure 1 shows the development of total emissions of $\mathrm{CO}_{2}$ in the $\mathrm{EU} 27, \mathrm{EU}$ 15 and in the Czech Republic. The trend of emissions of $\mathrm{CO}_{2}$ in European countries are decreasing, the only exception was the period between the years 
2003 and 2006. This situation could have been caused by economic conditions before the financial crisis that occurred approximately from 2007 to 2010 and a possible efficiency of emission allowances. During the financial crisis the amount of production of goods and services dramatically decreased in all member states of the European Union.

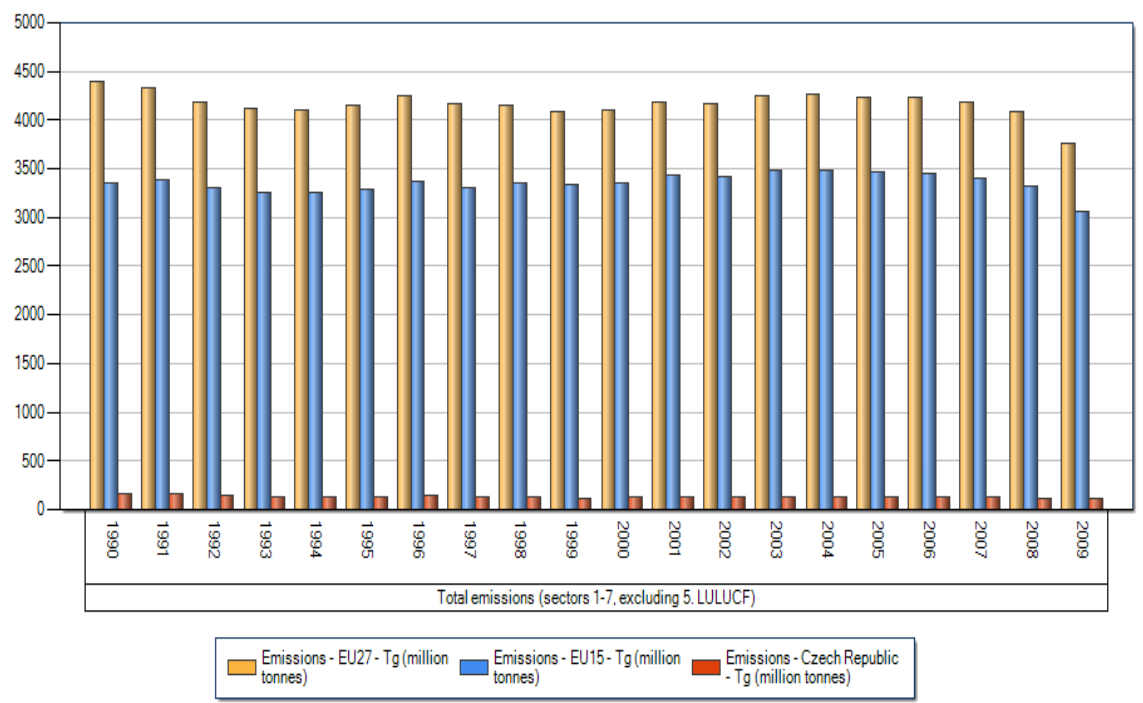

Figure 1: Total emissions of $\mathrm{CO}_{2}$ in EU 27, EU 15 and in the Czech Republic from 1990 to 2009. (Source: http://dataservice.eea.europa.eu /PivotApp/pivot.aspx?pivotid=475 [4].)

Figure 2 shows emission shares of $\mathrm{CO}_{2}$ in member states of the European Union. As can be seen, the Czech Republic (approximately 10000000 inhabitants) is the eighth largest polluter in EU 27 with emissions of $\mathrm{CO}_{2}$ in the amount of 113,388 Tg (million tons). The emission share of the Czech Republic is $3.0 \%$. The largest polluter of the EU 27 is Germany with a share of $21.0 \%$ and the least polluting country is Malta with a share of $0.1 \%$.

The table 1 shows the amount of emission allowances of five companies with the highest amount of $\mathrm{CO}_{2}$ pollution in the Czech Republic. These companies have obtained presented allowances in the second phase of implementation of the European Union Emission Trading Scheme (2008 - 2012).

The largest Czech polluter is a company called ArcelorMittal Ostrava a. s. This company is a producer of hot metal, steel and rolled products. Power plants of the company CEZ, a. s., which produces electrical energy, takes the second to the fourth position of the largest polluters. The latter is the largest polluter of $\mathrm{CO}_{2}$ in the Czech Republic in general. The fifth largest polluter is a coal power plant of Sokolovska uhelna, a. s. - Vresova. 

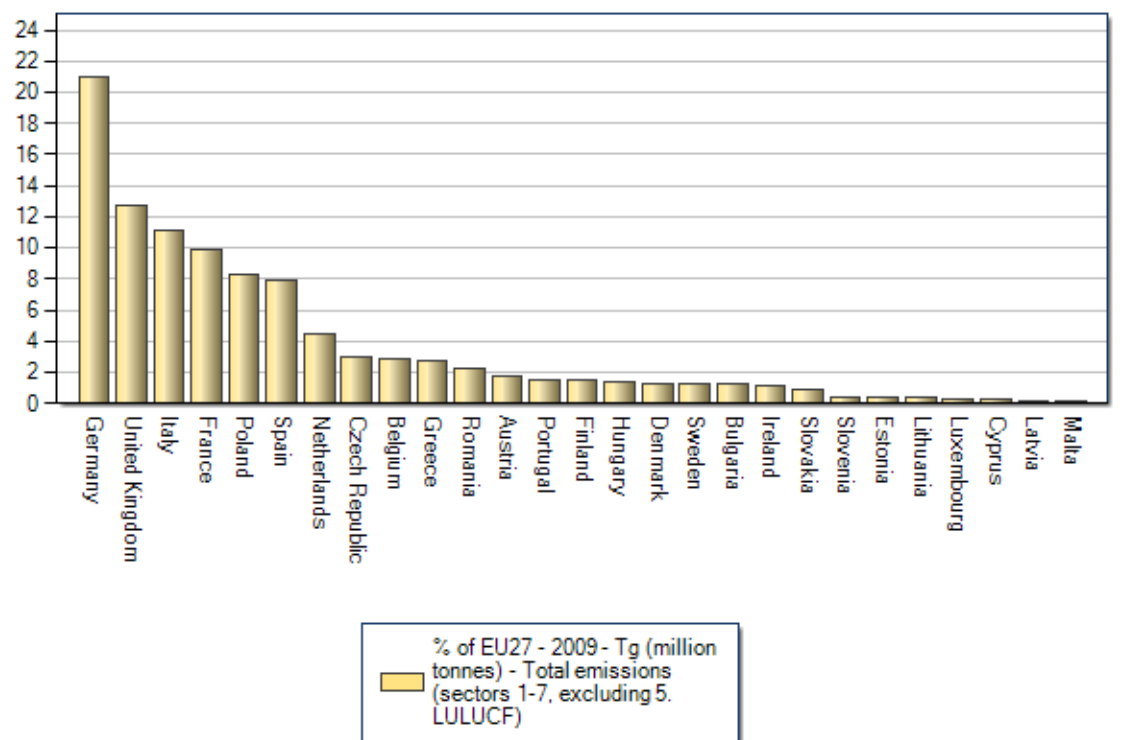

Figure 2: Emission shares of CO2 by country in EU 27 in 2009. (Source: http://dataservice.eea.europa.eu /PivotApp/pivot.aspx?pivotid=475 [4].)

Table 1: $\quad$ Five largest polluters of $\mathrm{CO}_{2}$ in the Czech Republic.

\begin{tabular}{|c|l|c|}
\hline Order & \multicolumn{1}{|c|}{ Company } & $\begin{array}{c}\text { Amount of Allowances } \\
\text { (pcs) }\end{array}$ \\
\hline 1. & ArcelorMittal Ostrava a.s. & $6,958,508$ \\
\hline 2. & CEZ, a. s. - Power plant Pocerady & $6,696,795$ \\
\hline 3. & CEZ, a. s. - Power plant Prunerov 2 & $6,335,369$ \\
\hline 4. & CEZ, a. s. - Power plant Tusimice 2 & $5,309,817$ \\
\hline 5. & $\begin{array}{l}\text { Sokolovska uhelna, a. s. - Power plant } \\
\text { Vresova }\end{array}$ & $4,478,948$ \\
\hline
\end{tabular}

Source: http://www.energostat.cz/emisni-povolenky-jako-vazny-problemenergetiky-v-cr.html [5].

\section{Emission trading in the European Union}

The main goal of the European Union Emission Trading Scheme (EU ETS) is to reduce and control the air pollution by carbon dioxide $\left(\mathrm{CO}_{2}\right)$ caused by all member states in the EU. A trade with allowances is a market based tool [6]. This trading scheme is one of the largest in the world and it is connected with meeting the criteria set in the Kyoto Protocol that the EU joined. This system is based on a cost-effective and an economically efficient method that tries to 
ensure competitiveness of the European companies obliged to obtain allowances for their production [7].

Due to the costs, time period for preparation, information of companies that are obliged to obtain pollution permits, preparing infrastructure for monitoring of actual emissions, their reporting and verification and of course due to other important reasons the process of implementation was divided into three basic phases that will take place 15 years in total.

The first phase started on $1^{\text {st }}$ January 2005 and finished on $31^{\text {st }}$ December 2007. This three-year phase was important for a preparation of the following two phases. This time period led to the establishment of price of carbon (the price of allowances is generally set by supply and demand at the time of transaction) and set of caps on national allocations of allowances. These caps have made traded allowances scarce and have forced all companies to reduce their emissions of green house gasses or buy other allowances. However, these transactions increase the costs of the companies and influence the profit or loss of that subject. All the EU member states had to prepare their own national allocation plans that set the total quantity of allowances for each period according to the ETS Directive. At least $95 \%$ of allowances were given to the companies free of charge during this period.

The second phase of implementation is dated from $1^{\text {st }}$ January 2008 to $31^{\text {st }}$ December 2012. This five-year period is crucial for all the EU member states that must implement rules into the national law and must comply with emissions targets under the Kyoto Protocol. At least $90 \%$ of all allowances were given to the companies free of charge during this period. It is possible to state that present allocation scheme is based mainly on grandfathering of allowances because only $10 \%$ of allowances are being auctioned.

The final eight-year phase will start on $1^{\text {st }}$ January 2013 and will be crucial for trading with the allowances in comparison with last two phases that were based mainly on their grandfathering. The system of auctioned allowances will increase and change the structure of the market. All involved companies will have to control the quantity of allowances and improve them according to their actual needs. If there is a lack of them, they must buy appropriate amount of allowances or decrease emissions of greenhouse gases or decrease their market share during this time period [8].

In Cihakova et al. [9] the authors present that the empirical studies encourage the implementation of free market tools in order to achieve the solution of determinate environmental problems and free market environmentalism is not based on taxation or other kinds of environmental regulations. As the system of implementation of emission allowances is set by the EU, a question arises of whether this situation could not harm the industry and competitiveness of European companies in comparison with other producers mainly from Asia that are not obliged to reduce their emissions of greenhouse gases. 


\section{Pollution permits - environmental issue in financial accounting and reporting under the Czech legislation}

Financial accounting is a tool to collect the information required to be disclosed to external stakeholders of a company, whereas a financial report is a platform for sharing this information. Financial report consists of financial statements which give a picture of a financial position of the company (balance sheet), its performance (income statement), cash flow etc.

In the past, environmentally related issues were not included in financial reporting. This has changed with the increasing extent of environmental costs, environmental management started to become an important issue in financial markets during the 1990s [10].

The main environmental topics in a company's financial accounting are the recognition, measurement and disclosure of environmentally related economic impacts on business and a company value. Environmental issues in financial accounting and reporting are concerned with revenues and expenses influencing the performance which is shown in the income statement, as well as with assets and liabilities which are shown in the statement of the financial position (balance sheet). In order to meet the objectives of financial statements and to be comparable, reports are assumed to be prepared on the basis of general accounting concepts and principles but the economic results of a company can differ substantially because they are influenced by local financial accounting rules which differ among jurisdictions.

\subsection{Pollution permits and tradable emission allowances as an accounting item}

In all countries, companies are allowed to pollute the environment as long as they do not exceed legal emission standards. The right to pollute is specifically certified by emission allowances. The total amount of pollution is strictly limited through the total number of pollution permits issued. An emission allowance is a certified right that allows a company to discharge a certain amount of pollution into the natural environment within a specified time limit.

Emission allowance can be understood either as a licence to pollute or as a right to emit a specific level of pollutants in a specific period of time [10]. In 2003, the definitions were set by the European Parliament and the Council: “...' 'allowance' means an allowance to emit one tonne of carbon dioxide equivalent during a specified period, which shall be valid only for the purposes of meeting the requirements of ... Directive and shall be transferable in accordance with the provisions of ... Directive;..." [11]. Greenhouse gas emissions permit means the permit issued and it "... shall include a description of: (a) the installation and its activities including the technology used; (b) the raw and auxiliary materials, the use of which is likely to lead to emissions of gases ...; (c) the sources of emissions of gases ... from the installation; and (d) the measures planned to monitor and report emissions ..." [11]. 
Proposed by the European Financial Reporting Advisory Group (EFRAG), emission allowance is recognised as intangible assets. According to Mladek, intangible assets are recognized by applying the following criteria:

- It arises from law, contract or some other claims or obligations.

- It does not arise from law or contract but is separable (can be sold, transferred, licensed, rented or exchanged) either individually or together with another assets or liabilities.

- It does not arise from law or contract, is not separable but is the difference between the amount paid for a business and the fair value of that business's net assets [12].

\subsection{Emission allowances under Czech accounting legislation}

Financial accounting in the Czech Republic is regulated by national legislation in three levels: Accounting act, Decree of the Czech Republic Ministry of Finance and Czech accounting standards.

In terms of emission allowances, changes in the Czech accounting legislation took place in October 2005 responding to the Act No. 695/2004 Coll., on Conditions for Trading in Greenhouse Gas Emissions, in which Directive 2003/87/EC on Emissions Trading was transposed [2].

In the Czech accounting legislation there is no definition of an asset; intangibles do not exist in current assets and an item is recognized as a fixed intangible asset if its useful lifetime exceeds one year and acquisition costs exceed the value limit specified by the accounting entity. Rules for recognition of emission allowances differ - they are recognized as an intangible fixed asset always, regardless of their acquisition costs and useful lifetime [13, 14].

Currently in the Czech Republic the emission market as well as the auction is not active. Since 2006 related first holders have acquired emission allowances in the form of government grants. Such emission allowance is valued by replacement costs. In the Czech Republic the costs of the emission allowances are set by the Energy Regulatory Office according to the chosen spot market and its weighted arithmetical average of the settlement prices and volume of the emission trade. Since 2010 BleuNext Market in France has been functioning. There the trade volume of the emission allowances is the largest in the European Union. The average costs of the emission allowance were calculated for 358.25 CZK - 14.83 EUR in the year 2010 and 349.84 CZK - 14.48 EUR in the year 2011 per allowance $[15,16]$.

When the emission allowance is consumed the operating expenses increase and at the same time the value of the government grant decreases together with the increase of the operating revenue. A financial report (balance sheet) has to show the decrease of the asset value when an emission allowance is consumed. We can say that in a situation of consumption of the granted emission allowances in a full amount, the profit (loss) of accounting period is not influenced by these transactions.

Acquisition of the emission allowances by the purchase is valued in acquisition costs, which includes all additional cost of the acquisition (i.e. 
commissions etc.). A consumption of the allowances is valued by the FIFO method ("first in, first out") only. If the company pollutes more than how many emission allowances it holds, it is recommended to disclose this difference as an estimated accrued item; on the other hand it is not recommended to create commissions for emission allowances.

\subsection{Illustrative example of the accounting and reporting the emission allowances in Czech legislative conditions}

In the year 20XX operator receives government grant of 100 emission allowances valued by 40 EUR per allowance. He sells 30 allowances for 24 EUR per allowance. Then he purchases 10 allowances for 20 EUR per allowance and 10 for 28 EUR per allowance. Surrender of allowances is estimated at 85 pieces. On the balance sheet date, the market value of purchased allowances decreases to 16 EUR/piece.

A received government grant increases the value of intangible fixed assets and grants related to assets to 4,000 EUR. A sale of 30 allowances increases bank account and revenues by a sale price of 720 EUR and at the same time an expense is increased and intangible assets decreased by acquisition costs of these allowances which is 1,200 EUR. By the same value of 1,200 EUR the grant is reduced and it influences the revenue as well. Purchases of the allowances at the emission market increase value of intangible fixed assets by 200 EUR (1st purchase) and 280 EUR (2nd purchase) and reduce our bank account. At the end of the year 20XX we have to disclose estimated accrued item related to surrender of purchased allowances which will be made in April 20XX+1. This transaction is valued according to FIFO valuation method (i.e. 10 pieces for $20 \mathrm{EUR} /$ piece and 5 pieces for $28 \mathrm{EUR} /$ piece). At the balance sheet date, the market value of purchased allowances decreases to $16 \mathrm{EUR} /$ piece, we have to create adjustments to remaining emission allowances (5 pieces) which influence intangible fixed assets as well as operating expenses by 60 EUR (calculated according to the FIFO methods as well).

The following table 2 illustrates the impact of emission allowances accounting on a financial reporting namely on a balance sheet.

Table 2: $\quad$ Balance Sheet reporting of emission allowances and related items.

\begin{tabular}{|c|c|c|c|}
\hline \multicolumn{4}{|c|}{ Balance Sheet as of $31^{\text {st }}$ December, 20XX (in EUR) } \\
\hline \multirow{2}{*}{\multicolumn{2}{|c|}{$\begin{array}{c}\text { ASSETS } \\
\text { Fixed assets }\end{array}$}} & LIABILI & \\
\hline & & \multicolumn{2}{|c|}{ Equities } \\
\hline Emission allowances & 3280 & Profit & 320 \\
\hline Adjustments to allowances & & \multicolumn{2}{|c|}{ Other/current liabilities } \\
\hline \multicolumn{2}{|c|}{ Current assets } & Grants related assets & 2800 \\
\hline Bank account & 240 & Estimated accruals & 340 \\
\hline$\sum A S S E T S$ & 3460 & NLIABILITIES & 3460 \\
\hline
\end{tabular}

Source: Authors' own calculation. 
The balance sheet shows a result of the chosen transaction connected with the emission allowances only. This simple example confirms that these transactions significantly influence the structure and values of reported asset and liability items. The performance of the company is influenced as well, namely in the part of operating income.

\section{Conclusion}

It can be said that the Czech legislation has adopted European Union rules concerning pollution and greenhouse gas emission. The directive 2003/87/EC on Emissions Trading was transposed to the Czech Act No. 695/2004 Coll., on Emissions Trading. It has influenced the Czech financial accounting rules as well. Emissions of $\mathrm{CO}_{2}$ are decreasing and the situation could be caused either by accepted emission legislation or by a recession of national as well as international markets.

Concerning the emission trades, the Czech market is not still active and the cost of the emission allowances is set by Energy Regulatory Office according to the chosen spot market and its weighted arithmetical average of the settlement prices and the volume of the emission trade.

We could argue that from the point of view of the financial accounting, the recognition of emission allowances as intangible assets which is proposed by EFRAG and generally accepted is not entirely accurate. This item could be recognized also as marketable securities or inventory. In the Czech accounting system emission allowances are disclosed as fixed asset because intangibles are not placed in current assets. Finally, we can state that emission allowances and related transactions significantly influence a financial position and a performance of a company which is reported in its financial statements.

\section{Acknowledgement}

This paper was written in accordance with a research project "Analysis of Processing Accounting Information with Focus on Satisfaction with Present Accounting Software Products" solved by Technical University of Liberec, Faculty of Economics.

\section{References}

[1] Townley, R. S., So Much Carbon, So Little Time: State Options for Effective Regulation of Mobile Source Emissions of Greenhouse Gases. The University of Memphis Law Review, 39(1), pp. 193-228, 2008.

[2] Act No. 695/2004 Coll., on Conditions for Trading in Greenhouse Gas Emissions.

[3] Cló, S., The effectiveness of the EU Emissions Trading Scheme. Climate Policy, 9(3), pp. 227-241, 2009.

[4] European Environment Agency, http://dataservice.eea.europa.eu 
[5] ENERGOSTAT, www.energostat.cz

[6] Energy policy and the transition to a low-carbon economy. $O E C D$ Economic Surveys, 2009(13), 2009.

[7] Nimmo, B. \& Armellini, A., EU temporarily shuts emissions trading system; member states blamed. MCClatchy - Tribune Information Services, 2011.

[8] Benz, E., Löschel, A. \& Sturm, B., Auctioning of CO2 emission allowances in Phase 3 of the EU Emissions Trading Scheme. Climate Policy, 10(6), pp. 705-718, 2010.

[9] Čihaková, S.A., Černíková, M. \& Dubová, M., Historical contamination and brownfield management: what does econimic theory say about it? Villacampa, Y. \& Brebbia, C.A. (eds). Ecosystems and Sustainable Development VIII, WIT Press: Ashurst, pp. 339-352, 2011.

[10] Schaltegger, S. \& Burritt, R., Contemporary Environmental Accounting: Issues, Concepts and Practice, Greenleaf Publishing Limited: UK, pp. 162203, 2000.

[11] Directive 2003/87/EC of the European Parliament and of the Council, of 13 October 2003 establishing a scheme for greenhouse gas emission allowance trading within the Community and amending Council Directive 96/61/EC. Official Journal of the European Union, L 275/32-46 Online. eurlex.europa.eu/LexUriServ/LexUriServ.do?uri=OJ:L:2003:275:0032: 0032: EN:PDF

[12] Mládek, R., Postupy účtování podle IFRS / IFRS Policies and Procedures, Leges: Praha, pp. 225-252, 2009.

[13] Act No. 563/1991 Coll., on Accounting. www.mvcr.cz

[14] Decree of Czech Republic Ministry of Finance No. 500/2002 Coll., on Accounting of Entrepreneurs. www.mfcr.cz

[15] Average cost of emission allowances 2010. Energy Regulatory Office, http://www.eru.cz/user_data/files/cenova\%20rozhodnuti/CR\%20teplo/cena \%20povolenky_2010.pdf

[16] Average cost of emission allowances 2011. Energy Regulatory Office, http://www.eru.cz/user_data/files/sdeleni_elektro2/Oceneni\%20povolenky_ darovaci\%20dan_2011.pdf 